\title{
PERAN CITRA MEREK MEMEDIASI PENGARUH E-WOM TERHADAP MINAT BELI SMARTPHONE SAMSUNG DI KOTA DENPASAR
}

\author{
Yande Agus Ardana ${ }^{1}$ \\ Ni Made Rastini2 \\ ${ }^{1,2}$ Fakultas Ekonomi dan Bisnis Universitas Udayana, Bali, Indonesia \\ 1e-mail : agusardhana@gmail.com
}

\begin{abstract}
ABSTRAK
Minat beli terhadap suatu produk muncul karena adanya dasar kepercayaan terhadap suatu produk yang diiringi dengan kemampuan untuk membeli produk. Penelitian ini bertujuan untuk mengetahui peran citra merek memediasi pengaruh e-WOM terhadap minat beli. Penelitian ini dilakukan di Kota Denpasar dengan objek penelitian adalah konsumen smartphone Samsung dengan menggunakan 110 responden. Metode pengumpulan sampel yang digunakan adalah non propability sampling dengan teknik analisis data menggunakan analisis jalur. Hasil penelitian ini menunjukkan bahwa e-WOM berpengaruh positif dan signifikan terhadap citra merek, e-WOM berpengaruh positif dan signifikan terhadap minat beli, citra merek berpengaruh positif dan signifikan terhadap minat beli serta citra merek dapat memediasi pengaruh e-WOM terhadap minat beli. Pihak manajemen Samsung perlu memperhatikan komunikasi e-WOM yang terjadi lebih bersifat komunikasi yang positif seperti komunikasi tentang keunggulan smartphone samsung dan harus berusaha membangun opini yang baik kepada masyarakat mengenai smartphone Samsung agar lebih mudah untuk memunculkan minat beli dari konsumen.
\end{abstract}

Kata Kunci: citra merek, e-wom, minat beli, smartphone

\begin{abstract}
Purchase intention against a product arises due to basic confidence in a product that is accompanied with the ability to purchase the product. This research aims to know the role of brand image mediate the influence of e-WOM against the purchase intention. This research was conducted in the city of Denpasar with the object of research is the consumer smartphone Samsung using 110 respondents. Sample collection method used is non propability sampling with data analysis techniques using path analysis. The results of this study indicate that e-WOM effect positively and significantly to the brand image, e-WOM effect positively and significantly to purchase intention, brand image effect positively and significantly to purchase intention as well as brand image can be mediate the influence of $e$-WOM interest against the purchase intention. Samsung's management needs to pay attention to communication e-WOM happens more positive communication as communication about superiority of samsung smartphones and should be trying to build a good community opinion regarding Samsung smartphone to make it easier to bring up the interest of consumers to buy.
\end{abstract}

Keywords: brand image, e-wom, purchase intention, smarthphone 


\section{PENDAHULUAN}

Perkembangan teknologi informasi menyebabkan perubahan yang signifikan terhadap kehidupan masyarakat terutama dalam hal bersosialisasi dan berkomunikasi. Saat ini kemajuan teknologi informasi mendorong masyarakat dalam era peradaban baru yaitu era informasi. Teknologi informasi memungkinkan manusia untuk memperoleh informasi dari tempat yang berjauhan dalam waktu yang singkat dan dengan biaya yang murah. Seiring perkembangan teknologi informasi tersebut, alat komunikasi dua arah berupa telepon genggam juga telah berkembang menjadi telepon pintar (smartphone). Fungsi smartphone yang semakin beragam saat ini sangat menarik minat masyarakat untuk menggunakannya.

Saat ini keberadaan smartphone sudah beralih menjadi barang kebutuhan sekunder, serta kondisi demografis Indonesia yang merupakan negara dengan jumlah penduduk terbesar urutan ke empat di dunia memicu timbulnya semakin banyak perusahaan-perusahaan produsen smartphone mengisi pasar di Indonesia.

Tingginya permintaan konsumen terhadap produk smartphone membuat persaingan yang sangat ketat atara perusahaan-perusahaan produsen smartphone yang ada dan membuat masing-masing perusahaan saling berlomba untuk memenuhi keingin dan kebutuhan konsumen yang selalu berubah-ubah dengan cara selalu menginovasi produk mereka dengan teknologi dan fitur terbaru. Banyaknya jenis dan merek smartphone yang beredar menyebabkan konsumen menjadi semakin kritis, cermat, dan selektif dalam memilih suatu produk yang 
akan dibeli. Kondisi yang demikian mengharuskan produsen untuk bekerja lebih keras dalam memasarkan produk serta membangkitkan minat beli dari konsumen.

Menurut Randi (2016), menyatakan bahwa Minat beli merupakan salah satu tahap penting lainnya yang harus diperhatikan oleh para pemasar dikarenakan minat merupakan suatu kondisi yang mendahului individu mempertimbangkan atau membuat keputusan untuk memilih sebuah produk atau layanan jasa. Menurut schiffman dan kanuk dalam maghfiroh (2016), menyatakan bahwa minat beli adalah suatu bentuk pikiran yang nyata dari beberapa merek yang tersedia dalam periode waktu tertentu. Minat beli konsumen untuk melakukan pembelian dapat muncul akibat dari adanya rangsangan (stimulus) yang ditawarkan oleh perusahaan. Masing-masing stimulus tersebut dirancang untuk mempengaruhi tindakan pembelian oleh konsumen.

Menurut Simamora (2012:106), menyatakan bahwa minat beli terhadap suatu produk muncul karena adanya dasar kepercayaan terhadap suatu produk yang diiringi dengan kemampuan untuk membeli produk. Minat beli sangat berhubungan dengan kemungkinan konsumen melakukan pembelian yang di dorong oleh motivasi-motivasi tertentu. Chung et al. (2012), menyatakan bahwa minat pembelian dapat digunakan untuk mengukur tingkat transformasi pelanggan ke dalam perilaku pembelian terhadap produk tertentu, dan dapat digunakan sebagai indeks untuk memprediksi pengambilan keputusan pembelian konsumen. Semakin tinggi minat beli maka semakin tinggi kesempatan pembelian.

Kemajuan teknologi juga telah merubah cara masyarakat dalam melakukan interaksi sosial. Smartphone yang berbasis internet dan dengan fasilitas media 
sosial membuat pengguna dapat dengan mudah berpartisipasi dalam komunikasi atau berbagi informasi melalui media online seperti jejaring social facebook, twitter, instagram, whatsapp, line, dll. Perkembangan teknologi informasi juga telah membawa perubahan bagi perkembangan dunia bisnis, hal tersebut dimanfaatkan oleh pelaku bisnis untuk bersaing dalam melakukan kegiatan pemasaran, salah satunya adalah dengan menggunakan word of mouth (WOM).

Menurut Bataineh (2015), menyatakan bahwa perkembangan internet telah mempengaruhi kemampuan komunikasi dan telah memperkuat skala dan cakupan komunikasi dari mulut ke mulut atau WOM, dan telah mepresentasikan makna dasar dari electronic word of mouth (e-WOM) menjadi sebuah konsep yang baru dari WOM yang memberikan tranparansi dan akses yang mudah untuk mendapatkan informasi melalui internet, hal itulah yang membuat para pemasar lebih tertarik untuk terlibat dalam menggunakan WOM sebagai sarana pemasaran. Menurut Jalilvand (2011), menyatakan bahwa $e$-WOM menjadi sebuah "venue" atau sebuah tempat yang sangat penting untuk konsumen mem-berikan opininya dan dianggap lebih efektif di-bandingkan WOM ofline, karena tingkat aksesibilitas dan jangkauannya yang lebih dalam Torlak et al. (2014), menyatakan bahwa eWOM dapat digambarkan sebagai cara komunikasi yang memberikan informasi kepada konsumen tentang penjual dan penggunaan produk dan layanan melalui teknologi berbasis internet. E-WOM mengacu pada pernyataan positif atau negatif yang dibuat oleh pelanggan berpotensial, aktual, atau mantan pelanggan tentang produk atau perusahaan, yang tersedia untuk banyak orang dan lembaga melalui Internet Jalilvand (2011). E-WOM lebih efektif daripada promosi langsung yang 
dilakukan pemasar karena konsumen lebih mudah terpengaruh dan lebih mudah percaya oleh rekomendasi orang lain yang sudah merasakan manfaat dari suatu produk. Secara umum komunikasi Electronic Word of mouth (e-WOM) adalah perkembangan dari komunikasi Word of mouth (WOM) yang dipengaruhi dari adanya internet.

Konsumen menjadi bagian yang memiliki potensi luar biasa dalam pemberitaan sebuah produk. Berbagai informasi yang bermanfaat dan berbagai pendapat dari orang lain yang positif terkait dengan suatu brand maka e-WOM dapat mendorong timbulnya citra merek Samuel dan Lianto (2014). Informasi yang beredar dari konsumen bisa bersifat positif atau negatif dapat mempengaruhi citra merek dari produk menjadi baik atau buruk.

Menurut Simamora dalam Sangadji dan Sopiah (2013:327), mengemukakan bahwa citra merek adalah seperangkat asosiasi unik yang ingin diciptakan atau dipelihara oleh pemasar. Asosiasi-asosiasi itu menyatakan apa sesungguhnya merek dan apa yang dijanjikan kepada konsumen. Fahrian (2015), menyatakan bahwa citra merek merupakan hasil pandangan atau persepsi konsumen terhadap suatu merek tertentu, yang didasarkan atas pertimbangan dan persepsi yang akurat dari suatu merek. Menurut Moksaoka (2016), menyatakan bahwa citra merek memberikan jaminan kepada konsumen akan produk mereka sehingga minat beli konsumen dengan produk dengan merek tertentu meningkat karena konsumen tidak memiliki kekhawatiwan terhadap produk dengan merek tersebut.

Pengguna smartphone yang terus meningkat memicu timbulnya semakin banyak perusahaan-perusahaan produsen smartphone mengisi pasar di Indonesia, 
diantaranya Samsung, Apple, Asus, Oppo, Xiaomi, Vivo, Advan, Sony, LG dll. Saat ini perusahaan smartphone yang menjadi pemimpin pasar global adalah Samsung.

Kesalahan pada baterai telah membuat Samsung melakukan dua kali penarikan ulang produk. Kasus ini bahkan berakhir pada penghentian penjualan dan penghentian produksi Samsung Galaxy Note 7. Komunikasi e-WOM yang terjadi lebih banyak yang bersifat negatif dibandingkan dengan komunikasi yang bersifat positif yang disebarkan netizen melalui dunia maya, hal tersebut akan sangat mempengaruhi citra merek dari perusahaan samsung dan khususnya terhadap citra merek untuk produk smartphone Samsung Galaxy Note 7. Dengan adanya penurunan dari citra merek smartphone Samsung menjadi semakin buruk serta pemberitaan melalui komunikasi e-WOM di dunia maya yang lebih banyak bersifat negatif sangat mempengaruhi dari penurunan minat beli dari konsumen terhadap produk Samsung.

Alasan peneliti melakukan studi ini adalah adanya ketidakkonsistenan hasil penelitian yang telah dilakukan sebelumnya. Penelitian sebelumnya yang dilakukan oleh Torlak et al. (2014) menyatakan bahwa e-WOM tidak berpengaruh atau tidak menunjukkan hasil yang positif terhadap minat beli, sedangkan penelitian yang sudah dilakukan oleh Elseidi dan El-Baz (2016) menyatakan bahwa e-WOM berpengaruh signifikan positif terhadap citra merek, sikap merek dan minat beli konsumen. Sebagai objek penelitian, peneliti tertarik menggunakan smartphone Samsung karena adanya masalah bisnis yang terjadi sehingga 
mengalami penurunan penjualan dari tahun 2014 hingga tahun 2016 dan variable citra merek digunakan sebagai variable pemediasi atara e-WOM dan minat beli.

Konsumen memiliki keragaman yang menarik untuk dipelajari karena konsumen meliputi seluruh individu dari berbagai usia, latar belakang budaya, pendidikan, dan keadaan sosial ekonomi lainnya. Oleh karena itu, sangatlah penting untuk mempelajari bagaimana konsumen berperilaku dan faktor-faktor apa saja yang mempengaruhi perilaku tersebut. Perilaku konsumen pada hakikatnya untuk memahami mengapa konsumen melakukan dan apa yang mereka lakukan. Schiffman dan Kanuk (2008:6), mengemukakan bahwa studi perilaku konsumen adalah suatu studi mengenai bagaimana seorang individu membuat keputusan untuk mengalokasikan sumber daya yang tersedia (waktu, uang, usaha, dan energi).

Perilaku konsumen sangat dipengaruhi oleh keadaan dan situasi lapisan masyarakat dimana ia dilahirkan dan berkembang. Ini berarti konsumen berasal dari lapisan masyarakat atau lingkungan yang berbeda akan mempunyai penilaian, kebutuhan, pendapat, sikap, dan selera yang berbeda-beda, sehingga pengambilan keputusan dalam tahap pembelian akan dipengaruhi oleh beberapa faktor.

Faktor yang mempengaruhi perilaku konsumen menurut Kotler (2008:25) terdiri dari: 1) Faktor Kebudayaan. Faktor kebudayaan berpengaruh luas dan mendalam terhadap perilaku konsumen. Faktor kebudayaan terdiri dari: budaya, subbudaya, kelas sosial. 2) Faktor Sosial. Selain faktor budaya, perilaku seorang konsumen dipengaruhi oleh faktor-faktor sosial seperti kelompok acuan, keluarga serta status sosial. 3) Faktor Pribadi. Faktor pribadi yang memberikan kontribusi 
terhadap perilaku konsumen terdiri dari: usia dan tahap siklus hidup, pekerjaan dan lingkungan ekonomi, gaya hidup, kepribadian dan konsep diri. 4) Faktor Psikologis. Pilihan pembelian seseorang dipengaruhi oleh empat faktor psikologi utama yaitu motivasi, persepsi, pembelajaran, serta keyakinan dan pendirian.

Berdasarkan beberapa definisi yang telah disebutkan di atas dapat disimpulkan bahwa perilaku konsumen adalah semua kegiatan, tindakan, serta proses psikologis pada saat sebelum membeli, ketika membeli, dan setelah pembelian. Mempelajari atau menganalisis perilaku konsumen merupakan sesuatu yang sangat kompleks, terutama karena banyaknya variabel yang mempengaruhinya dan kecenderungannya untuk saling berinteraksi.

Menurut Kotler \& Keller (2012:512), word of mouth marketing adalah kegiatan pemasaran melalui perantara orang ke orang baik secara lisan, tulisan, maupun alat komunikasi elektronik yang berhubungan dengan pengalaman pembelian jasa atau pengalaman menggunakan produk atau jasa. Electronic word of mouth (e-WOM) merupakan pengembangan dari Word Of Mouth (WOM) secara elektronik dengan penggunaan teknologi digital atau internet.

Penggunaan internet telah mengubah cara konsumen dalam berkomunikasi dan berbagai pendapat dan ulasan mengenai produk atau jasa yang pernah dikonsumsi. Hennig Thurau et al. (2004) dalam Lin et al. (2012), menyatakan bahwa komunikasi e-WOM adalah pernyataan positif atau negatif yang dilakukan oleh potensial, aktual, atau mantan pelanggan tentang produk atau yang perusahaan buat tersedia untuk banyak orang dan lembaga melalui internet, misalnya chat room, blog, forum internet, dan lain-lain. Abubakar (2016), 
menyatakan bahwa e-WOM didefinisikan berbagai pernyataan positif atau negatif yang dibuat oleh seseorang atau pelanggan sebelumnya tentang sebuah produk, pelayanan atau perusahaan yang disediakan untuk masyarakat luas melalui internet. Secara umum dapat didefinisikan bahwa e-WOM merupakan bentuk komunikasi yang berkembang dari WOM karena adanya pengaruh dari perkembangan teknologi dan internet. e-WOM dapat berupa pernyataan positif atau negative yang dibuat oleh seseorang atau mantan pelanggan berdasarkan pengalaman yang dirasakan mengenai penggunaan suatu produk atau jasa.

Ambarawati (2015) menyatakan seseorang atau individu akan mengalami proses pemikiran terlebih dahulu yang membentuk suatu persepsi sebelum akhirnya akan timbul minat untuk membeli. Menurut Mehta dalam Hidayati (2013) mengatakan bahwa minat beli didefinisikan sebagai kecenderungan konsumen untuk membeli suatu merek atau mengambil tindakan yang berhubungan dengan pembelian yang diukur dengan tingkat kemungkinan konsumen melakukan suatu pembelian.

Pengertian merek menurut The American Marketing Association dalam Kotler \& Keller (2012:241), mendefinisikan brand atau merek sebagai, suatu nama, istilah, tanda, simbol, desain, atau kombinasi dari semuanya yang dimaksudkan untuk mengidentifikasikan suatu barang atau jasa dari satu penjual atau sekelompok penjual dan untuk membedakannya dari kompetitor lain. Randy (2013) menyatakan bahwa keberadaan merek dianggap sebagai pilar bisnis sehingga dapat menarik minat konsumen untuk memakai produk tersebut. 
Citra merek sebagai presepsi konsumen tentang sebuah merek yang ditunjukkan dan berasosiasi dalam ingatan konsumen. Kotler dan Amstrong (2008:227), mendefinisikan citra merek sebagai seperangkat keyakinan konsumen mengenai merek tertentu. Tjiptono (2011:49), menyatakan bahwa Citra merek adalah deskripsi asosiasi dan keyakinan konsumen terhadap merek tertentu.

Minat beli menciptakan suatu motivasi yang terus terekam dalam benak konsumen dan menjadi suatu keinginan yang sangat kuat yang pada akhirnya ketika seorang konsumen harus memenuhi kebutuhannya akan mengaktualisasikan apa yang ada didalam benaknya itu.

Menurut Simamora dalam Sangadji dan Sopiah (2013:327), mengemukakan bahwa citra merek adalah seperangkat asosiasi unik yang ingin diciptakan atau dipelihara oleh pemasar. Asosiasi-asosiasi itu menyatakan apa sesungguhnya merek dan apa yang dijanjikan kepada konsumen. Hidayati (2013) menyatakan bahwa citra merek dapat dianggap sebagai jenis asosiasi yang muncul dalam benak konsumen ketika mengingat suatu merek tertentu. Asosiasi tersebut secara sederhana dapat muncul dalam bentuk pemikiran atau citra tertentu yang dikaitkan dengan suatu merek.

Menurut Maghfiroh (2016) berpendapat bahwa citra merek akan mempengaruhi persepsi setiap konsumen, dimana masyarakat akan mempunyai kesan positif pada merek tersebut sebab masyarakat saat ini sangat selektif dalam memilih merek apa yang sesuai dengan kebutuhan mereka. Hidayati (2013) menyatakan bahwa citra merek yang baik merupakan salah satu aset bagi perusahaan, karena citra merek tersebut mempunyai suatu dampak pada setiap 
persepsi konsumen, di mana masyarakat akan mempunyai kesan positif terhadap merek tersebut.

Christie (2016) menyatakan bahwa penggunaan internet telah mengubah cara konsumen dalam berkomunikasi dan berbagai pendapat dan ulasan mengenai produk atau jasa yang pernah dikonsumsi. Hennig Thurau et al.. (2004) dalam Lin et al., (2012) menyatakan bahwa komunikasi e-WOM adalah pernyataan positif atau negatif yang dilakukan oleh potensial, aktual, atau mantan pelanggan tentang produk atau yang perusahaan buat tersedia untuk banyak orang dan lembaga melalui internet, misalnya chat room, blog, forum internet, dan lain-lain. Abubakar (2016) menyatakan bahwa e-WOM didefinisikan berbagai pernyataan positif atau negative yang dibuat oleh seseorang atau pelanggan sebelumnya tentang sebuah produk, pelayanan atau perusahaan yang disediakan untuk masyarakat luas melalui internet.

Penelitian yang dilakukan oleh Samuel dan Lianto (2014), Adriyati dan Indriani (2017), Anggitasari (2016), Nurrohman (2016), Jafari et al. (2015), dan Luong et al. (2017) menyatakan bahwa e-WOM berpengaruh positif dan signifikan terhadap citra merek. Semakin besar dan kuat komunikasi e-WOM yang dilakukan serta informasi yang beredar bersifat positif terhadap suatu produk maka citra merek yang ditimbulkan di benak konsumen mengenai produk tersebut akan semakin baik juga.

Penelitian yang dilakukan oleh Samuel dan Lianto (2014), Adriyati dan Indriani (2017), Anggitasari (2016), Nurrohman (2016), Jafari et al. (2015), dan Luong et al. (2017) menyatakan bahwa e-WOM berpengaruh positif dan 
signifikan terhadap citra merek. Semakin besar dan kuat komunikasi e-WOM yang dilakukan serta informasi yang beredar bersifat positif terhadap suatu produk maka citra merek yang ditimbulkan di benak konsumen mengenai produk tersebut akan semakin baik juga.

$\mathrm{H}_{1}$ : e-WOM berpengaruh positif dan signifikan terhadap citra merek.

Penelitian yang dilakukan oleh Sarah dan Rubiyanti (2016), Putri dan Prabowo (2015), Sa'ait et al. (2016), Cong dan Zheng (2017), dan Tariq et al. (2017), Elseidi dan El-Baz (2016), Anggitasari (2016), Samuel dan Lianto (2014), Indriyati dan Indriani (2017) menemukan hasil bahwa e-WOM berpengaruh signigikan positif terhadap minat beli. Semakin baik atau bagus review seseorang pada blog atau web maka akan menimbulkan minat beli yang tinggi terhadap suatu produk. Namun, hasil yang berbeda ditunjukkan pada penitian Torlak et al. (2014) yang menyatakan bahwa e-WOM tidak berpengaruh positif terhadap minat beli.

$\mathrm{H}_{2}$ : e-WOM berpengaruh positif dan signifikan terhadap kebijakan minat beli.

Penelitian yang dilakukan oleh Maghfiroh dkk. (2016), Pradipta dan Mashariono (2015), Randi (2016), Zaman (2014), He et al. (2013), Wang dan Tsai (2014), Ningrum (2016), Kamilah dan Wahyuati (2017), Lien et al. (2015), Suwarduki dkk. (2016), Fahrian dkk. (2015), Anggitasari (2016), dan Priyono dkk. (2016) menyatakan bahwa citra merek berpengaruh positif dan signifikan terhadap minat beli. Semakin besar dan kuat citra merek suatu produk maka minat beli konsumen akan semakin besar juga.

$\mathrm{H}_{3}$ : Citra merek berpengaruh positif dan signifikan terhadap minat beli. 
Penelitian yang dilakukan oleh Torlak et al. (2014), Majid (2014), Jalilvand dan Samiei (2012), Anggitasari (2016), Siswanto (2017), Samuel dan Lianto (2014) Elseidi dan El-Baz (2016), Adriyati dan Indriani (2017) menyatakan bahwa bahwa e-WOM berpengaruh positif terhadap minat beli dengan citra merek sebagai variabel mediasi.

$\mathrm{H}_{4}$ : Citra merek berpengaruh positif dalam memediasi e-WOM dengan Minat Beli.

\section{METODOLOGI PENELITIAN}

Variabel eksogen atau variabel independen adalah variabel yang mempengaruhi atau yang menjadi sebab perubahannya atau timbulnya variabel terikat (Sugiyono, 2013:39). Variabel eksogen dalam penelitian ini adalah eWOM (X). Variabel endogen atau variabel dependen adalah variabel yang dipengaruhi atau menjadi akibat karena adanya variabel independen (Sugiyono, 2013:39). Variabel endogen dalam penelitian ini adalah minat beli (Y2). Variabel mediasi adalah variabel yang secara teoritis mempengaruhi hubungan antara variabel indpenden dan dependen, tetapi tidak dapat diamati dan diukur. Variabel ini merupakan variabel penyela/antara yang terletak diantara variabel independen dan dependen, sehingga variabel independen tidak langsung mempengaruhi berubahnya atau timbulnya variable dependen. Variabel intervening dalam penelitian ini adalah citra merek (Y1).

Populasi adalah wilayah generalisasi yang terdiri atas objek atau subjek yang mempunyai kualitas dan karakteristik tertentu yang ditetapkan oleh peneliti untuk dipelajari dan kemudian ditarik kesimpulannya (Sugiyono, 2013:80). Dalam penelitian ini yang menjadi populasi adalah massyarakat yang berusia minimal 17 
tahun ke atas atau sudah mengenyam pendidikan SMA dan berdomisili di Kota Denpasar serta belum pernah menggunakan smartphone Samsung sebelumnya. Jumlah populasi tidak dapat teridentifikasi karena tidak adanya sumber data yang menunjukkan jumlah masyarakat yang belum pernah menggunakan smartphone Samsung sebelumnya.

Sampel adalah bagian dari jumlah dan karakteristik yang dimiliki oleh populasi tersebut. (Sugiyono, 2013:81). Sekaran (2014) mengemukakan ukuran sampel yang baik adalah 5 - 10 kali jumlah variabel atau indikator dalam penelitian. Penelitian ini menggunakan 11 indikator sehingga dengan menggunakan estimasi berdasarkan jumlah parameter diperoleh ukuran sampel sebesar 55 - 110 responden. Jumlah dari sampel responden yang akan diuji di dapat dari hasil perhitungan sebagai berikut :

$$
\begin{aligned}
\text { Jumlah Responden } & =11 \times 10 \\
& =11 \text { indikator } \times 10 \\
& =110 \text { responden }
\end{aligned}
$$

Menurut Sekaran (2014) parameter sampel yang baik adalah sekitar 70-140 sampel. Jadi, dengan dipilihnya 110 responden artinya sudah sesuai dengan kriteria yang ditentukan.

Metode pengumpulan sampel dalam penelitian ini menggunakan metode non probability sampling, dimana metode ini merupakan metode pengambilan sampel yang tidak memberi peluang/kesempatan sama bagi setiap unsur atau anggota populasi untuk dipilih menjadi sampel dengan teknik pengambilan sampel yang digunakan dalam penelitian ini adalah purposive sampling dimana teknik dalam menentukkan sampelnya berdasarkan dengan pertimbangan tertentu. 
Sampel dalam penelitian ini adalah masyarakat Kota Denpasar dengan kriteria berusia 17 tahun ke atas dan memiliki minat beli terhadap produk smartphone merek Samsung.

Metode pengumpulan data dalam penelitian ini adalah metode wawancara dengan kuesioner. Kuesioner merupakan teknik pengumpulan data yang dilakukan dengan cara memberi seperangkat pertanyaan atau pernyataan tertulis kepada responden untuk dijawabnya (Sugiyono, 2013:142). Pertanyaan dalam kuesioner dibuat dengan menggunakan skala Likert dari pertanyaan yang diberikan kepada responden. Teknik analisis data yang digunakan dalam penelitian ini adalah teknik analisis jalur (path analysis). Teknik analisis jalur ini dapat didefinisikan sebagai perluasan dari analisis linier berganda dalam memperkirakan hubungan kausalitas antara yang telah ditetapkan berdasarkan teori.

\section{HASIL DAN PEMBAHASAN}

Responden penelitian digambarkan secara umum dengan menyajikan karakteristiknya dilihat dari beberapa variabel demografi yaitu jenis kelamin, usia, pekerjaan, pendidikan, dan gaji responden.

Dilihat dari pengelompokan jenis kelamin, responden perempuan sebesar 38,18 persen, sedangkan responden laki-laki sebesar 61,82 persen usia. Dilihat dari usia, mayoritas responden berusia 17 - 21 tahun sebanyak 58,18 persen, responden berusia 22 - 26 tahun sebanyak 36,36 persen, lalu responden berusia 32 - 36 tahun sebanyak 3,63 persen, dan responden berusia diatas 36 tahun sebanyak 1,82 persen. 
Tabel 1.

Karakteristik Responden

\begin{tabular}{|c|c|c|c|c|}
\hline No & Variabel & Klasifikasi & Jumlah & Persentase \\
\hline \multirow[t]{3}{*}{1} & Jenis Kelamin & Perempuan & 68 & 61,82 \\
\hline & & Laki-laki & 42 & 38,18 \\
\hline & Total & & 110 & 100,00 \\
\hline \multirow[t]{6}{*}{2} & Usia & 17 - 21 tahun & 64 & 58,18 \\
\hline & & $22-26$ tahun & 40 & 36,36 \\
\hline & & $27-31$ tahun & 0 & 0,00 \\
\hline & & $32-36$ tahun & 4 & 3,64 \\
\hline & & diatas 36 tahun & 2 & 1,82 \\
\hline & Total & & 110 & 100 \\
\hline \multirow[t]{6}{*}{3} & Pekerjaan & Pelajar/mahasiswa & 81 & 73,64 \\
\hline & & Karyawan Swasta & 13 & 11,82 \\
\hline & & PNS & 5 & 4,55 \\
\hline & & Pengusaha & 9 & 8,18 \\
\hline & & Lain-lain & 2 & 1,82 \\
\hline & Total & & 110 & 100 \\
\hline \multirow[t]{6}{*}{4} & Pendidikan Terakhir & SMA & 43 & 39,09 \\
\hline & & Diploma & 2 & 1,82 \\
\hline & & $\mathrm{S} 1$ & 61 & 55,45 \\
\hline & & S2 & 4 & 3,64 \\
\hline & & S3 & 0 & 0,00 \\
\hline & $\begin{array}{l}\text { Total } \\
\text { Pendanatan/uno }\end{array}$ & & 110 & 100 \\
\hline \multirow[t]{5}{*}{5} & $\begin{array}{l}\text { Pendapatan/uang } \\
\text { saku }\end{array}$ & $\begin{array}{l}\text { kurang dari Rp. } 1,000,000,- \\
\text { Rp. } 1,000,000,-\mathrm{s} / \mathrm{d}\end{array}$ & 44 & 40,00 \\
\hline & & $\begin{array}{c}\text { Rp.3,000,000,- } \\
\text { Rp.3,000,000,- s/d }\end{array}$ & 47 & 42,73 \\
\hline & & Rp.5,000,000,- & 12 & 10,91 \\
\hline & & diatas Rp.5,000,000,- & 7 & 6,36 \\
\hline & Total & & 110 & 100 \\
\hline
\end{tabular}

Sumber: Data diolah, 2017

Dilihat dari pekerjaan, mayoritas responden pelajar/mahasiswa sebanyak 73,63 persen, responden karyawan swasta sebanyak 11,82 persen, responden PNS sebanyak 4,54 persen, responden pengusaha sebanyak 8,18 persen, dan responden lainnya sebanyak 1,81 persen. 
Dilihat dari tingkat pendidikan terakhir, mayoritas responden SMA 39,09 persen, responden diploma 1,81 persen, responden $\mathrm{S} 1$ 55,45 persen, dan responden S2 3,63 persen.

Dilihat dari pendapatan atau uang saku per bulan, mayoritas responden dengan pendapatan atau uang saku Rp.1,000,000,- sampai dengan Rp.3,000,000,sebanyak 42,72 persen, responden dengan pendatan atau uang saku kurang dari Rp.1,000,000,- sebanyak 40 persen, responden dengan pendapatan atau uang saku Rp.3,000,000,- sampai dengan Rp.5,000,000,- sebanyak 10,9 persen, dan responden dengan pendapatan atau uang saku diatas Rp.5,000,000,-- sebanyak 6,36 persen.

Tabel 2.

Ringkasan Koefisien Jalur

\begin{tabular}{llllll}
\hline Regresi & Koef. Regresi Estandar & $\begin{array}{l}\text { Standar } \\
\text { Error }\end{array}$ & t hitung & p value & Keterangan \\
\hline $\mathrm{X} \rightarrow \mathrm{Y} 1$ & 0,707 & 0,039 & 10,402 & 0,000 & Signifikan \\
$\mathrm{Y} 1 \rightarrow \mathrm{Y} 2$ & 0,563 & 0,082 & 6,039 & 0,000 & Signifikan \\
$\mathrm{X} \rightarrow \mathrm{Y} 2$ & 0,415 & 0,058 & 2,307 & 0,023 & Signifikan \\
\hline
\end{tabular}

Keterangan :

$\mathrm{X}=\mathrm{e}-\mathrm{WOM}$

$\mathrm{Y} 1=$ Citra Merek

Y2 = Minat Beli

Sumber: Data diolah, 2017

Tabel 2 menjelaskan bahwa variabel e-WOM (X) berpengaruh signifikan terhadap citra merek (Y1), variabel citra merek (Y1) berpengaruh signifikan terhadap minat beli (Y2), dan variabel e-WOM (X) berpengaruh signifikan terhadap minat beli (Y2). Variabel e-WOM berpengaruh paling besar dengan nilai loading factor 0,707 terhadap variabel citra merek dan variable e-WOM juga berpengaruh terhadap variabel minat beli dengan nilai loading factor sebesar 0,415 serta terdapat pengaruh tidak langsung melalui variabel citra merek dengan nilai loading factor 0,563 terhadap variabel minat beli. Maka dapat dihitung 
pengaruh langsung, pengaruh tidak langsung dan pengaruh total antar variabel dalam Tabel 3.

\section{Tabel 3.}

Ringkasan Pengaruh Langsung, Pengaruh Tidak Langsung dan Total Pengaruh Antar Variabel Penelitian

\begin{tabular}{|c|c|c|c|}
\hline \multirow[t]{2}{*}{ Variabel } & \multicolumn{3}{|c|}{$\mathbf{X}$} \\
\hline & PL & PTL & TP \\
\hline$M$ & 0,707 & & 0,707 \\
\hline $\mathrm{Y}$ & 0,415 & 0,234 & 0,649 \\
\hline
\end{tabular}

Keterangan:

$\mathrm{PL} \quad=$ Pengaruh Langsung

PTL = Pengaruh Tidak Langsung

$\mathrm{TP} \quad=$ Total Pengaruh

$\mathrm{X}=\mathrm{e}-\mathrm{WOM}$

$\mathrm{Y} 1=$ Citra Merek

Y2 = Minat Beli

Sumber: Data diolah, 2017

Pada Tabel 3 pengaruh langsung $\mathrm{X}$ terhadap $\mathrm{Y} 1$ adalah 0,707. Tidak terdapat pengaruh tidak langsung sehingga pengaruh totalnya 0,677. Pengaruh langsung $\mathrm{X}$ terhadap $\mathrm{Y} 2$ adalah 0,415 . Pengaruh tidak langsung $\mathrm{X}$ terhadap $\mathrm{Y} 2$ melalui Y1 diperoleh dari $0,415 \times 0,563=0,234$. Oleh karena itu, pengaruh total $\mathrm{X}$ terhadap Y2 melalui Y1 adalah sebesar $0,415+0,234=0,649$. Ini berarti bahwa terdapat pengaruh tidak langsung variabel e-WOM terhadap minat beli melalui citra merek.

Nilai probabilitas sebesar $0,000<0,05$. Hal ini berarti $\mathrm{H}_{0}$ ditolak dan $\mathrm{H}_{1}$ diterima. Dengan demikian e-WOM berpengaruh positif dan sginifikan terhadap citra merek.Hubungan positif dan signifikan antara variabel e-WOM terhadap variabel citra merek, dengan demikian e-WOM berpengaruh positif dan signifikan terhadap citra merek. Intensitas komunikasi e-WOM yang tinggi mengenai suatu produk akan mempengaruhi persepsi konsumen terhadap produk tersebut dan pada akhirnya persepsi konsumen akan membentuk citra merek dari dari produk 
tersebut. Penelitian yang dilakukan oleh Kazmi dan Mehmood (2016) juga memperoleh hasil bahwa e-WOM berpengaruh positif dan signifikan terhadap citra merek.

Nilai probabilitas sebesar $0,023<0,05$. Hal ini berarti $\mathrm{H}_{0}$ ditolak dan $\mathrm{H}_{1}$ diterima. Dengan demikian e-WOM berpengaruh positif dan signifikan terhadap minat beli. Hubungan positif dan signifikan antara variabel e-WOM terhadap variabel minat beli menyatakan bahwa semakin sering komunikasi e-WOM terjadi mengenai suatu produk maka akan menimbulkan rasa ingin tahu di benak konsumen yang pada akhirnya berujung pada keinginan untuk memiliki dan minat beli dari konsumen akan tumbuh seiring berjalannya waktu. Penelitian yang dilakukan Fan dan Miao (2012) menyatakan bahwa e-WOM berpengaruh positif pada minat beli.

Nilai probabilitas sebesar $0,000<0,05$. Hal ini berarti $\mathrm{H}_{0}$ ditolak dan $\mathrm{H}_{1}$ diterima. Dengan demikian citra merek berpengaruh positif dan signifikan terhadap minat beli. Hubungan positif dan signifikan antara variabel citra merek terhadap niat beli, hal ini berarti bahwa citra merek dapat memberikan kontribusi dalam membentuk minat beli konsumen. Semakin baik citra merek dari suatu produk atau perusahaan maka kontribusi dalam memikat minat beli akan mudah tercapai. Hasil penelitian diatas sejalan juga dengan penelitian yang dilakukan oleh Wang dan Tsai (2014) yang menyatakan bahwa citra merek berpengaruh positif dan signnifikan terhadap minat beli.

Berdasarkan perhitungan, didapatkan nilai $\mathrm{Z}$ hitung sebesar 6,668 yang artinya lebih besar dari 1,98 (6,668 > 1,98). Dapat disimpulkan bahwa citra merek 
mampu memediasi pengaruh e-WOM terhadap minat beli. Variabel citra merek sebagai variabel mediasi berpengaruh signifikan secara tidak langsung terhadap minat beli melalui variabel e-WOM. Dengan demikian hasil ini sejalan dengan penelitian dari Torlak et al. (2014), menyatakan bahwa pelaksanaan e-WOM positif yang didukung oleh citra merek yang kuat, secara tidak langsung dapat mempengaruhi tindakan pembelian konsumen.

Berdasarkan hasil penelitian yang diperoleh dalam analisis data dapat diketahui bahwa nilai sig. $\mathrm{t}$ sebesar 0,000 dengan nilai koefisien beta sebesar 0,707. Nilai sig. $\mathrm{t}$ yang memperlihatkan nilai $0,000<0,050$, maka dapat disimpulkan bahwa terdapat pengaruh positif dan signifikan antara e-WOM terhadap citra merek. Hasil tersebut memperlihatkan bahwa intensitas komunikasi e-WOM yang tinggi akan mempengaruhi persepsi konsumen dan pada akhirnya persepsi konsumen akan membentuk citra merek dari smartphone Samsung. Hasil penelitian ini didukung oleh hasil penelitian sebelumnya yang dilakukan oleh Kazmi dan Mehmood (2016), menyatakan bahwa e-WOM berpengaruh positif dan signifikan terhadap citra merek, Samuel dan Lianto (2014), menyatakan bahwa e-WOM berpengaruh positif dan signifikan terhadap citra merek, Adriyati dan Indriani (2017), menyatakan bahwa e-WOM berpengaruh positif terhadap citra merek, Anggitasari (2016), menyatakan bahwa terdapat pengaruh positif dan signifikan e-WOM terhadap citra merek, Jafari et al. (2015), menyatakan bahwa e-WOM mempunyai dampak yang signifikan terhadap citra merek, dan Luong et al. (2017), menyatakan bahwa e-WOM mempunyai dampak positif yang besar terhadap citra merek. 
Berdasarkan hasil penelitian yang diperoleh dalam analisis data dapat diketahui bahwa nilai sig. $\mathrm{t}$ sebesar 0,023 dengan nilai koefisien beta sebesar 0,415. Nilai sig. $\mathrm{t}$ yang memperlihatkan nilai $0,023<0,050$, maka dapat disimpulkan bahwa terdapat pengaruh positif dan signifikan antara e-WOM terhadap minat beli. Hasil tersebut memperlihatkan bahwa semakin sering komunikasi e-WOM terjadi maka akan menimbulkan rasa ingin tahu di benak konsumen untuk mencari lebih banyak informasi yang pada akhirnya berpengaruh terhadap keyakinan dan kepercayaan konsumen terhadap smartphone Samsung berdasarkan komunikasi yang terjadi sehingga dapat memunculkan keinginan untuk memiliki smartphone Samsung dan minat beli dari konsumen akan tumbuh seiring berjalannya waktu. Hasil penelitian ini didukung oleh hasil penelitian sebelumnya yang dilakukan oleh Fan dan Miao (2012), menyatakan bahwa eWOM berpengaruh positif pada minat beli, Sarah dan Rubiyanti (2016), menyatakan bahwa e-WOM berpengaruh secara signifikan terhadap minat beli, Putri dan Prabowo (2015), menyatakan bahwa e-WOM memiliki pengaruh yang positif dan signifikan terhadap minat beli, Sa'ait et al. (2016), menyatakan bahwa e-WOM berdampak positif terhadap minat beli naum tidak signifikan, Cong dan Zheng (2017), menyatakan bahwa e-WOM berpengaruh positif dan signifikan terhadap minat beli, dan Tariq et al. (2017), menyatakan bahwa e-WOM memiliki dampak yang positif dan kuat terhadap minat beli, Elseidi dan El-Baz (2016), menyatakan bahwa e-WOM berpengaruh positif dan signifikan terhadap minat beli,Anggitasari (2016), menyatakan bahwa terdapat pengaruh positif dan signifikan variabel e-WOM terhadap minat beli, dan Indriyati dan Indriani (2017), 
juga menemukan hasil bahwa e-WOM berpengaruh positif dan signifikan terhadap minat beli.

Berdasarkan hasil penelitian yang diperoleh dalam analisis data dapat diketahui bahwa nilai sig. $\mathrm{t}$ sebesar 0,000 dengan nilai koefisien beta sebesar 0,563. Nilai sig. $\mathrm{t}$ yang memperlihatkan nilai $0,000<0,050$, maka dapat disimpulkan bahwa terdapat pengaruh positif dan signifikan antara citra merek terhadap minat beli. Hasil tersebut memperlihatkan bahwa citra merek dari smartphone Samsung dapat memberikan kontribusi dalam membentuk minat beli konsumen. Semakin baik citra merek dari smartphone Samsung maka kontribusi dalam memikat minat beli akan mudah tercapai. Hasil penelitian ini didukung oleh hasil penelitian sebelumnya yang dilakukan oleh Wang dan Tsai (2014), yang menyatakan bahwa citra merek berpengaruh positif dan signnifikan terhadap mibat beli, Maghfiroh dkk. (2016), menyatakan adanya pengaruh yang positif dan signifikan variabel citra merek terhadap minat beli, Pradipta dan Mashariono (2015), menyatakan bahwa citra merek meiliki pengaruh positif dan signifikan terhadap minat beli, Arslan (2014), menyatakan bahwa citra merek berpengaruh positif terhadap minat beli, Wang dan Tsai (2014), menyatakan bahwa citra merek berpengaruh positif dan signifikan terhadap minat beli, Ningrum (2016), menyatakan bahwa citra merek berpengaruh signifikan terhadap minat beli, Kamilah dan Wahyuati (2017), menyatakan bahwa citra merek berpengaruh signifikan dan positif terhadap minat beli, Lien et al. (2015), menyatakan bahwa citra merek berpengaruh positif terhadap minat beli, Suwarduki dkk. (2016), menyatakan bahwa citra merek berpengaruh positif dan signifikan terhadap minat 
beli, dan Priyono dkk. (2016), menyatakan bahwa citra merek berpengaruh positif dan signifikan terhadap minat beli. Semakin besar dan kuat citra merek suatu produk maka minat beli konsumen akan semakin besar juga.

Berdasarkan hasil yang diperoleh melalui uji sobel dapat diketahui bahwa untuk signifikasi tidak langsung pengaruh kualitas produk terhadap loyalitas pelanggan melalui citra merek mendapatkan Z hitung yakni sebesar 6,0195 lebih besar dari t tabel yakni sebesar 1,9847. Hasil tersebut menyatakan bahwa pelaksanaan e-WOM yang didukung oleh citra merek yang kuat, secara tidak langsung dapat mempengaruhi minat beli konsumen terhadap smartphone Samsung. Hasil penelitian ini didukung oleh hasil penelitian sebelumnya yang dilakukan oleh Tariq et al. (2017), menyatakan bahwa citra merek memediasi penuh antara e-WOM terhadao minat beli, Jalilvand dan Samiei (2012) dalam penelitiannya menunjukkan bahwa citra merek dapat digunakan sebagai variabel pemediasi atara e-WOM dan minat beli, Anggitasari (2016), menyatakan adanya pengaruh positif dan signifikan anatara e-WOM terhadap minat beli melalui citra merek, Elseidi dan El-Baz (2016), dalam penelitiannya menunjukkan bahwa citra merek dapat memediasi pengaruh variabel e-WOM terhadap variabel minat beli, Adriyati dan Indriani (2017), dalam penelitiannya menunjukkan bahwa adanya pengaruh e-WOM terhadap minat beli yang dimediasi oleh citra merek.

Penelitian ini berimplikasi terhadap pengembangan konsep yang berkaitan dengan e-WOM, citra merek, dan minat beli smartphone Samsung di Kota Denpasar. Penelitian ini memperkaya bukti empiris peran citra merek memediasi pengaruh e-WOM terhadap minat beli. Hasil penelitian ini mendukung hasil studi 
bahwa citra merek yang baik akan mempengaruhi komunikasi e-WOM yang terjadi menjadi positif dan akhirnya mempengaruhi minat beli dari konsumen.

Berdasarkan hasil penelitian variabel e-WOM berpengaruh positif dan signifikan terhadap minat beli smartphone Samsung di Kota Denpasar. Rata-rata skor untuk variabel e-WOM sebesar 3,84. Ini artinya bahwa responden menganggap komunikasi e-WOM yang terjadi mengenai smartphone Samsung sudah baik. Untuk variabel citra merek sudah cukup dipersepsikan baik oleh responden terlihat dari rata-rata skor sebesar 3,96. Skor untuk variable minat beli sebesar 4,00. Ini mengindikasikan bahwa minat beli responden terhadap smartphone Samsung dapat dikatagorikan tinggi.

Secara keseluruhan hasil survey yang dilakukan mendapatkan hasil yang baik, maka dari itu pihak manajemen diharapkan mampu mempertahankan indikator-indikator yang sudah dianggap baik oleh responden dan meningkatkan indikator-indikator yang masih dianggap kurang oleh responden smartphone Samsung.

\section{SIMPULAN DAN SARAN}

Berdasarkan pembahasan hasil penelitian yang telah dilakukan, maka dapat disimpulkan bahwa e-WOM berpengaruh positif dan signifikan terhadap citra merek. Hal ini berarti semakin baik komunikasi e-WOM yang terjadi maka akan semakin baik pula citra merek yang tercipta.

Citra merek berpengaruh positif dan signifikan terhadap minat beli. Hal ini berarti semakin baik citra merek yang dimiliki suatu produk atau perusahaan maka akan semakin tinggi keingin atau minat beli dari konsumen. 
e-WOM berpengaruh positif dan signifikan terhadap minat beli. Hal ini berarti semakin tinggi intensitas komunikasi e-WOM yang terjadi akan meningkatkan rasa ingin tahu konsumen mengenai hal yang dikomunikasikan sehingga akan menimbulkan minat beli seiring dengan berjalannya waktu.

Citra merek mampu memediasi pengaruh e-WOM terhadap minat beli. Hal ini berarti citra merek mampu memberikan dampak yang lebih besar pada komunikasi e-WOM yang terjadi terhadap minat beli.

Berdasarkan hasil penelitian, pembahsan dan kesimpulan maka saran yang dapat diberikan adalah pihak manajemen Samsung perlu memperhatikan komunikasi e-WOM yang terjadi lebih bersifat komunikasi yang positif agar meningkatkan minat beli konsumen terhadap smartphone Samsung.

Perlu adanya pengawasan yang lebih teliti terhadap produk smartphone yang diproduksi agar tidak terjadi kesalahan teknis yang dapat mempengaruhi citra merek dari perusahaan sehingga dapat menurunkan minat beli dari konsumen.

Bagi peneliti selanjutnya untuk meningkatkan kualitas penelitian sebaiknya memperluas ruang lingkup penelitian dan menambahkan beberapa variabel seperti, persepsi harga, kualitas produk, gaya hidup.

\section{REFERENSI}

Abubakar, M. A., Mustafa I., and Pinar, S. 2016. eWOM, eReferral and gender in the virtual community. Marketing Intelligence \& Planning, 34 (5): 692-710.

Adriyati, R., dan Indriani, F. 2017. Pengaruh Electronic Word Of Mouth Terhadap Citra Merek Dan Minat Beli Pada Produk Kosmetik Wardah. Diponogoro Journal Of Management, 6 (4): 1-14. 
Anggitasari, A. M. 2016. Pengaruh Ewom Terhadap Brand Image Dan Brand Trust, Serta Dampaknya Pada Minat Beli Produk Smartphone Iphone (Studi Pada Masyarakat Di Yogyakarta). Jurnal Manajemen Bisnis Indonesia, 5 (3): 266-275.

Arslan, M., and Zaman, R. 2014. Impact of Brand Image and Service Quality on Consumer Purchase Intention: A Study of Retail Store in Pakistan. Research on Humanities and Social Sciences, 4 (22): 98-105.

Simamora, B. 2011. Memenangkan Pasar dengan Pemasaran Efektifdan Profitabel. Jakarta: PT. Gramedia Pustaka Utama

Chung, C. H., Chen, H. T., and Lin, C. Y. 2012. A Study of Brand Perception, Advertising Effectiveness and Relationship Quality on Purchase Intention, Journal of Data Analysis, 7 (5): 137 - 158.

Cong, Y., and Zheng, Y. 2017. A Literature Review of the Influence of Electronic Word-of-Mouth on Consumer Purchase Intention. Open Journal of Business and Management, 5 (1): 543-549.

Elseidi, R. I., and El-Baz, D. 2016. Electronic Word Of Mouth Effects On Consumers Brand Attitudes, Brand Image And Purchase Intention: An Empirical Study In Egypt. The Bussines and Management Review, 7 (5): 268-276.

Fahrian, F., Hasiolan, L. B., dan Haryono, A. T. 2015. Pengaruh Citra Merek, Lokasi, Kepercayaan Dan Kualitas Pelayanan Terhadap Minat Membeli Bbm Di Spbu Gasindo Mekar Putra Semarang. Journal of Management, 1 (1): 1-19.

Fan, Y., and Miao, Y. 2012. Effect Of Electronic Word-Of-Mouth On Consumer Purchase Intention: The Perspective Of Gender Differences. International Journal of Electronic Business Management, 10 (3): 175-181.

Ghozali, I. 2011. Aplikasi Analisis Mutivariate Dengan Program SPSS. Semarang: Badan Penerbit Universitas Diponegoro.

Hidayati, T. A., Suharyono dan Fanani, D. 2013. Pengaruh Citra Merek Terhadap Minat Beli Dan Keputusan Pembelian Konsumen. Jurnal Administrasi Bisnis, 2 (1): 162-171.

Humaira, A., dan Wibowo, L. A. 2016. Analisis Faktor Elektronik Word Of Mouth (Ewom) Dalam Mempengaruhi Keputusan Berkunjung Wisatawan. Tourism and Hospitality Essentials (THE) Journal, 6 (2): 1-12.

Jafari, S. M. B., Karimi, A., Forouzandeh, M., and Safahani, N. 2015. The Effect of Brand Commitment on e-WOM and Brand Image in the Mobile Market. Research Journal of Applied Science, 10 (10): 519-524. 
Jalilvand, M. R., and Samiei, N. 2012. The Effect Of Electronik Word Of Mouth on Brand Image and Purchase Intention: An empirical study in the automobile industry in Iran. Marketing Intelligence \& Planning, 30 (4): 460-476.

Kamilah, G., dan Aniek, W. 2017. Pengaruh Labelisasi Halal Dan Brand Image Terhadap Keputusan Pembelian Melalui Minat Beli. Jurnal Ilmu Dan Riset Manajemen, 6 (2): 1-18.

Kazmi, A., dan Mehmood, Q. S. 2016. The Effect Of Electronic Word Of Mouth Communication And Brand Image On Purchase Intention: A Case Of Consumer Electronics In Haripur, Pakistan. Management Science Letters, 6 (7): 499-508.

Kotler, P. 2008. Manajemen Pemasaran. Jilid 2, Edisi 12. Jakarta: Indeks

Kotler, P., and Keller K. L. 2012. Manajemen Pemasaran, Jilid 1, Edisi ke 13, Jakarta: Erlangga.

Lien, C., Wen M., Huang L., and Wu, K. 2015. Online Hotel Booking: The Effects Of Brand Image, Price, Trust And Value On Purchase Intentions. Asia Pacific Management Review, 20 (4): 210-218.

Luong, D., Vo, T. G., and Le, K. H. 2017. The Impact Of Electronic Word Of Mouth On Brand Image And Buying Decision: An Empirical Study In Vietnam Tourism. International Journal of Research Studies, 6 (1): 53-63.

Maghfiroh, A., Arifin, Z., dan Sunarti. 2016. Pengaruh Citra Merek Terhadap Minat Beli Dan Keputusan Pembelian (Survei pada Mahasiswa Program Studi Administrasi Binis Tahun Angkatan 2013/2014 Fakultas Ilmu Administrasi Universitas Brawijaya Malang Pembeli Indosat). Jurnal Administrasi Bisnis, 40 (1): 132-140.

Ningrum, I. T. J., dan Nilowardono, S. 2016. Pengaruh Event Dan Brand Image Terhadap Minat Beli Produk Rokok Sampoerna A Mild Pada Pt Hm Sampoerna Area Marketing Surabaya. e-Jurnal Manajemen Kinerja, 2 (1): 57-69.

Pradipta, H. O., dan Mashariono. 2015. Pengaruh Citra Merek, Periklanan Terhadap Minat Beli Konsumen Thermometer Onemed Di Surabaya. Jurnal Ilmu dan Riset Manajemen, 4 (7): 1-19.

Pratama, I G. B. A. C. D. E., Yasa, N. N. K., and Nurcahya, N. 2018. The Role of Brand Image in Mediating the Influence of Sponsorship on the Intention to Purchase. International Journal of Management and Commerce Innovation, 5 (2): 997-1003. 
Priyono, E., Haryono, A. T., dan Maria M. 2016. Analysis Pengaruh Citra Merek, Strategi Promosi, Atribut Produk, Harga Terhadap Minat Berkunjung Serta Pengaruhnya Terhadap Minat Beli (Studi Empiris Pada Pameran Computer Di Javamall Semarang). Journal of Management, 2 (2): 1-22.

Putri, L. E. D., dan Prabowo, F. S. A. 2015. Pengaruh Electronic Word Of Mouth (E-Wom) Terhadap Purchase Intention (Studi Kasus Pada Go-Jek Indonesia). e-Proceeding of Management, 2 (3): 2865-2871.

Randi dan Heryanto, M. 2016. Pengaruh Citra Merek Terhadap Minat Beli Pada Makanan Fast Food Ayam Goreng (Studi Pada Konsumen Texas Chicken Pekanbaru). Jurnal Online Mahasiswa Fakultas Ilmu Sosial dan Ilmu Politik, 3 (2): 1-9.

Riduwan dan Kuncoro. 2011. Cara Menggunakan dan Memakai Path Analysis (Analisis Jalur). Bandung: Alfabeta

Sa'ait, N., Kenyan, A., and Nazrin, M. F. 2016. The Effect of E-WOM on Customer Purchase Intention. International Academic Research Journal of Social Science, 2 (1): 73-80.

Samuel, H., dan Lianto, A. S. 2014. Pengaruh Analisis eWOM, Brand Image, Brand Trust dan Minat Beli Produk Smartphone di Surabaya. Jurnal Universitas Kristen Petra Surabaya, 8 (2): 47-54.

Sangadji, E.M., dan Sopiah. 2013. Perilaku Konsumen: Pendekatan Praktis Disertai: Himpunan Jurnal Penelitian. Yogyakarta: Penerbit Andi.

Sarah, T. M. S., dan Rubiyanti, R. N. 2016. Pengaruh Electronic Word Of Mouth Terhadap Minat Beli Pada Café Du71a Bandung. e-Proceeding of Management, 3 (2): 2087-2093.

Sarwono, J. 2012. Path Analysis, Aplikasi, Prosedur Analisis untuk Riset Skripsi, Tesis, dan Disertasi. Jakarta: PT. Elex Media Komputindo

Schiffman, L. G., and kanuk, L. 2008. Perilaku konsumen. Edisi 7. Jakarta: Indeks.

Sekaran, U. 2014. Metodologi Penelitian untuk Bisnis (Research Methods for Business). Buku 1 Edisi 4. Jakrta: Salemba Empat

Sugiyono. 2013. Metode Penelitian Pendidikan (Pendekatan Kualitatif, Kuantitatif, dan $R \& D)$. Bandung; Alfabeta.

Sulistyari, I. N., dan Yoestini. 2012. Analisis Pengaruh Citra Merek, Kualitas Produk, Dan Harga Terhadap Minat Beli Produk Oriflame (Studi Kasus 
Mahasiswi Fakultas Ekonomika dan Bisnis Jurusan Manajemn Universitas Diponegoro Semarang). Diponegoro Journal Of Management, 1 (1): 1-17.

Suwarduki, P. R., Yulianto, E., dan Mawardi, M. K. 2016. Pengaruh Electronic Word Of Mouth Terhadap Citra Destinasi Serta Dampaknya Pada Minat Dan Keputusan Berkunjung (Survei Pada Followers Aktif Akun Instagram Indtravel Yang Telah Mengunjungi Destinasi Wisata Di Indonesia). Jurnal Administrasi Bisnis (JAB), 37 (2): 1-10.

Tariq, M., Abbas, T., Abrar, M., and Iqbal, A. 2017. Ewom And Brand Awareness Impact On Consumer Purchase Intention: Mediating Role Of Brand Image. Pakistan Administrative Review, 1 (1): 84-102.

Tjiptono, F. 2011 . Brand Management \& Strategy. Yogyakarta : Andi

Torlak, O., Ozkara, B. Y., Tilaty, M. A., Cengiz, H., and Dulger, M. F. 2014. The Effect of Electronic Word of Mouth on Brand Image and Purchase Intention: An Application Concerning Cell Phone Brands for Youth Consumers in Turkey. Journal of Marketing Development and Competitiveness, 8 (2): 61-68.

Wang, Y., and Tsai, C. 2014. The Relationship Between Brand Image And Purchase Intention: Evidence From Award Winning Mutual Funds. The International Journal of Business and Finance Research, 8 (2): 27-40. 